in their account of Valentin Fernandez's visit to West Africa prior to 1506, report his statement that milho zaburro flourished in San Tomé where it was planted for the first time in 1502, having previously been shipped thither from the coast of Guinea. Here is evidence that mitho zaburro was a well-established crop on the coasts of Guinea before 1502. If milho zaburro is maize, then it could not possibly be a wellestablished crop on the coasts of Guinea if it was first introduced into Spain in 1494, which is the earliest date by which Columbus could have introduced this cereal. It follows that if milho zaburro is maize, it must have existed in West Africa long before Columbus.

It is necessary to show that milho zaburro is maize. Soares de Sousa (ref. 9, 162), writing in 1587, says: "Dá-se autro-mantimento, em todo o Brazil, natural da mesma tena, a qui os indios chamam ubatim, qué é o milho de Guiné, que em Portugal chamam Zaburro ..." Now milho de Guiné is still the name in Brazil for maize. A Portuguese dictionary of to-day gives: Zaburro, Indian corn, maize.

The question now arises: Who, then, brought maize to Africa before Columbus was born? My researches over the past seven years have now accumulated sufficient data ${ }^{10}$ to establish Arab-Negro contacts with the Americas beginning about A.D. 900.

University of the Witwatersrand, M. D. W. JEFFREYS

Johannesburg, South Africa.

${ }^{1}$ Goodwin, A. J. H., S. Afr. Areh. Bull., 8, No. 29 (1953),

"Burton, R. F., "Abeokuta and the Cameroon Mountain" (London $1863)$

"Moore, E. O. O., "History of Abeokuta" (London, 1916).

'Babalola, A., West African Rev., 23, No. 292 (1952).

"Burns, A., "A History of Nigeria" (London, 1929).

"Talbot, P. A., "Southern Nigeria" (Oxford, 1926).

"Meek, C. K.. "Tribal Studies in Northern Nigeria"' (Oxford, 1931) ; "A Sudanese Kingdom" (London, 1931).

${ }^{8}$ Monod, T., Teixeira, da Mota, and Mauny, T., "Description de la cóte Occidentale d'Afrique par Valentin Fernandez" (Bissau, 1951).

- Soares de Sousa, G., "Tratado descriptio do Brazil em 1587" (Rio de Janeiro, 1879).

${ }^{10}$ Jeffreys, M. D. W., Scientia, Juillet-Août (1953).

\section{Non-standard Radio Propagation}

Squadron Leader A. G. Sheffield, R.C.A.F. (VE3EB), has reported the following occurrence of non-standard radio propagation observed in Ottawa :

\begin{tabular}{|c|c|c|c|c|}
\hline Date & $\underset{(\text { Time }}{\text { Tim) }}$ & $\begin{array}{c}\text { Fre- } \\
\text { quency }\end{array}$ & Location & Remarks \\
\hline June 23 & $1900-2030$ & $\begin{array}{l}\text { 66- } 72 \\
\text { Mc./s. }\end{array}$ & $\begin{array}{l}\text { WADS-TV } \\
\text { Kansas City } \\
\text { (915 n.m.) }\end{array}$ & $\begin{array}{l}\text { Estimated signal } \\
\text { up to } 200 \text { micro- } \\
\text { volts (received } \\
\text { on indoor half- }\end{array}$ \\
\hline June 24 & $1300-1400$ & $\begin{array}{l}60-66 \\
\text { Mc./s. }\end{array}$ & $\begin{array}{l}\text { KMA-TV } \\
\text { Omaha, Neb. } \\
\text { (897 n.m.) }\end{array}$ & $\begin{array}{l}\text { Steady signal with } \\
\text { intermittent out } \\
\text { of phase com- } \\
\text { ponents displaced } \\
\text { approx. } 3 \text { micro- } \\
\text { seconds }\end{array}$ \\
\hline June 24 & $1300-1400$ & $\begin{array}{l}66-72 \\
\text { Mc./s. }\end{array}$ & Not identifted & $\begin{array}{l}\text { Weak signal, ori- } \\
\text { gin unknown }\end{array}$ \\
\hline
\end{tabular}

$\mathrm{He}$ comments: "During this period, other longrange reception was evident over the frequency range of 54-72 Mc./s., but there was no opportunity for identifying it. Tests were made using a horizontally polarized co-linear antenna array consisting of four dual-stacked elements about $80 \mathrm{ft}$. above ground; $360^{\circ}$ rotation of this antenna, which has a beamwidth to $3 \mathrm{db}$. points of about $10^{\circ}$, did not change the strength or otherwise affect the signals observed. For the duration of this extraordinary long range very high-frequency reception, normal signals of a few microvolts from television stations about 100-180 miles distant could not be obtained".

The Rockcliffe weather office of the Department of Transport has very kindly furnished weather maps and an interpretation for the period June 21-25. It appears that the conditions at the time are very common for the region; these are a weak frontal surface giving a stable layer at about $10,000 \mathrm{ft}$. for the period of abnormality together with a surface inversion at about $1,000 \mathrm{ft}$. during the nights. Radio-sonde data are normally available at several points on or near the path.

Pinetree Project Office,

P. G. Forsy't

No. 4 Temporary Building,

Ottawa, Canada. July 7.

\section{Zoological Nomenclature}

Notice is hereby given of the publication of the following cases in the Class Aves involving the possible use of its plenary powers by the International Committee on Zoological Nomenclature for the purposes specified in brackets against each entry. Full particulars of these cases have been published in the Bulletin of Zoological Nomenclature, in Triple-Part $1 / 3$ of Volume 9.

(1) Colymbus Linnæus, 1758, and Gavia (all uses prior to Gavia Forster, 1788) (suppression); (2) caspicus Hablizl, 1783, Colymbus (suppression); (3) cafra (Otis), cafer (Cuculus), sulphuratus (Cuculus), flavescens (Lanius), all of Lichtenstein, 1793 (sup pression); (4) nortoniensis Gmelin, 1789, Fringil. (suppression); (5) natka (Lanius) and septentrions:? (Lanius), both of Gmelin, 1788, and eimeen (Columba), unalaschkensis (Hirundo), borealis (Motu cilla), cirrhatus (Pelecanus), australis (Sterna), all of Gmelin, 1789 (suppression); (6) phaeus (Turdus), elegans (Motacilla), chlorotis (Muscicapa), all of Forster, 1794, and novaehollandiae Latham, 1790, Muscicapa (suppression); (7) Pyrrhocorax Tunstall, 1771 (validation, for the Chough); (8) philomelos Brehm, 1831, Turdus (validation, for the Song Thrush); (9) generic name Vermivora and trivial names lutea (Muscicapa), pensylvanica [sic] (Passer), americ. [sic] (Vermivora), all of Linnæus, 1776 (suppression); (10) migratoria Linnæus, 1766, Columba (validation, for the Passenger Pigeon) ; (11) Bubo Duméril, 1806, Coturnix Bonnaterre, 1790, Egretta Forster, 1817, Oriolus Linnæus, 1766 (validation, by suppression of senior homonyms published by Brisson in 1760); (12) Capella Frenzel, 1801 (validation, by suppression of Gallinago Brisson, 1760) ; (13) Myiobius Darwin, 1839 (validation and designation of type species); (14) cyanea Hume, 1877, Muscitrea (validation, by suppression of cyanea Vieillot, 1818, Muscicapa); (15) ferruginea Hodgson, 1845, Hemichelidon (validation, by suppression of ferruginea Merrem, 1784, Muscicapa).

Comments on the above cases should be sent to me as soon as possible.

Francis Hemming

(Secretary of the International Committee on Zoological Nomenclature)

28 Park Village East,

Regent's Park, London, N.W.1. 